\title{
PENGUATAN PEMBERDAYAAN EKONOMI KREATIF AGUNG HANDYCRAFT DESA KLEPU KECAMATAN CEPER KABUPATEN KLATEN
}

\author{
Nur Kholis ${ }^{1)}$, Hestin Mutmainah ${ }^{2)}$, Ida Ayu Kade Rachmawati Kusasih ${ }^{3)}$ \\ Sekolah Tinggi Ilmu Ekonomi (STIE) Surakarta, Indonesia \\ e-mail: nukonurkholis1988@gmail.com
}

\begin{abstract}
Covid-19 has a big impact on all groups, from the government to MSMEs. The smaller the opportunity to work, eventually many people have to rethink to pay for their lives. During this time of pandemic, home businesses are growing rapidly, one of which is Mr. Agung Santoso who is a Handycraft craftsman. $n$ implementing the Tri Dharma and having a vision and mission, Surakarta's high school of economics always provides assistance to MSME craftsmen around Solo Raya in improving the creative economy. Introduction to entrepreneurship, e-marketing and introduction to management and finance which are the main targets in the development of the Agung Handycraft business.
\end{abstract}

KEYWORDS: : Entrepreneurship, Creative Economy

\begin{tabular}{|c|c|c|}
\hline Accepted: & Reviewed: & Published: \\
January 04 2021 & January 09 2021 & February 15 2021 \\
\hline
\end{tabular}

\section{PENDAHULUAN}

Tahun 2020 membawa banyak cerita, tak hanya cerita perubahan pada seluruh aspek kehidupan dunia. Penyebaran virus Corona telah mengubah banyak rencana dan situasi perekonomian dunia termasuk Indonesia. Pada tahun 2020 indonesia mengalami resesi karena dampak pandemic covid-19 (Rohmi, 2020). Pertumbuhan ekonomi Indonesia minus hingga 5,32 persen pada triwulan II 2020. Dampak dari minusnya pertumbuhan ekonomi ini salah satunya peningkatan angka pengangguran dan penduduk miskin (Rohmi, 2020).

Covid-19 memiliki dampak yang besar bagi semua kalangan, mulai dari pemerintah sampai Usaha Mikro Kecil Menengah (UMKM). Hampir seluruh bidang mulai dari ekonomi, politik, social budaya hingga pendidikan juga ikuf berdampak. Tidak sedikit perusahaan yang mem-PHK karyawan dan banyak merumahkan pekerja-pekerja sehingga pengangguran meningkat (Aditya, 2020) 
Semakin kecil peluang bekerja akhirnya banyak orang harus berfikir ulang untuk membiaya hidupnya. Menjadi seorang wirausaha walaupun dalam skala mikro atau kecil menjadi pilihan (Mukaromah, 2020). Pada masa pendemi seperti ini usaha rumahan semakin tumbuh pesat, salah satu adalah bapak Agung Santoso yang merupakan pengrajin Handycraft.

Agung Handycraft beralamat di Ngaglik RT. 02/01, Klepu, Ceper Klaten Jawa Tengah. Berawal dari di rumahkan bapak Agung Santoso dari perusahaan tempat bekerja karena pandemi covid 19. Secara pasti Agung handycraft bertekad untuk mengembangkan usaha di bidang penyediaan souvenir dan handycraft yang benar dan baik. Tekad ini membuat agung handycraf menjadi lebih berkonsentrasi dan inovatif. Disamping itu diikuti dengan pemilihan serta penggunaan bahan baku yang benar, baik mengenai jenis, jumlah maupun kualitasnya akan menghasilkan produk yang baik.

Agung Handycraft ini pada awalnya adalah bertujuan hanya untuk memenuhi kebutuhan keluarga saja. Namun, sekarang bapak Agung memiliki tujuan sebagai berikut :

1. Perbaikan ekonomi dari masyarakat setempat dengan memberikan pekerjaan tambahan bagi warga sekitar.

2. Mengurangi pengangguran yang banyak terjadi di daerah lain dari pemudapemuda yang tidak melanjutkan pendidikan ke jenjang yang lebih tinggi.

3. Mengurangi kegiatan-kegiatan yang bersifat negatif bagi kaum muda di daerah tersebut.

4. Mengurangi limbah kaca yang tidak terpakai

Penggalian permasalahan-permasalahan yang dihadapi oleh Agung handycraft antara lain Produk hasil kerajinan masih bergantung kepengepul, sehingga bapak Agung tidak bisa menentukan harga jual sendiri. Sehingga Ketika tidak ada pesanan dari pengepul otomatis agung handycraf tidak beroperasi. Kemudian permasalah selanjutnya yaitu menjalankan usahanya tidak mengetahui seberapa laba dan tidak bisa memperkirakan biaya apa saja yang timbul dalam kegiatan usahanya. Keuangan yang dimiliki agung handycraf masih bercampur dengan kebutuhan keluarga.

Saat ini bapak Agung memiliki 7 orang karyawan yang berasal dari pemuda di sekitar rumahnya. Karyawan yang dimiliki bapak Agung berlatar belakang peendidikan yang bervariasi. Bapak Agung mengutamakan karyawan yang mau belajar dalam pembuatan kerajinan kapal. 

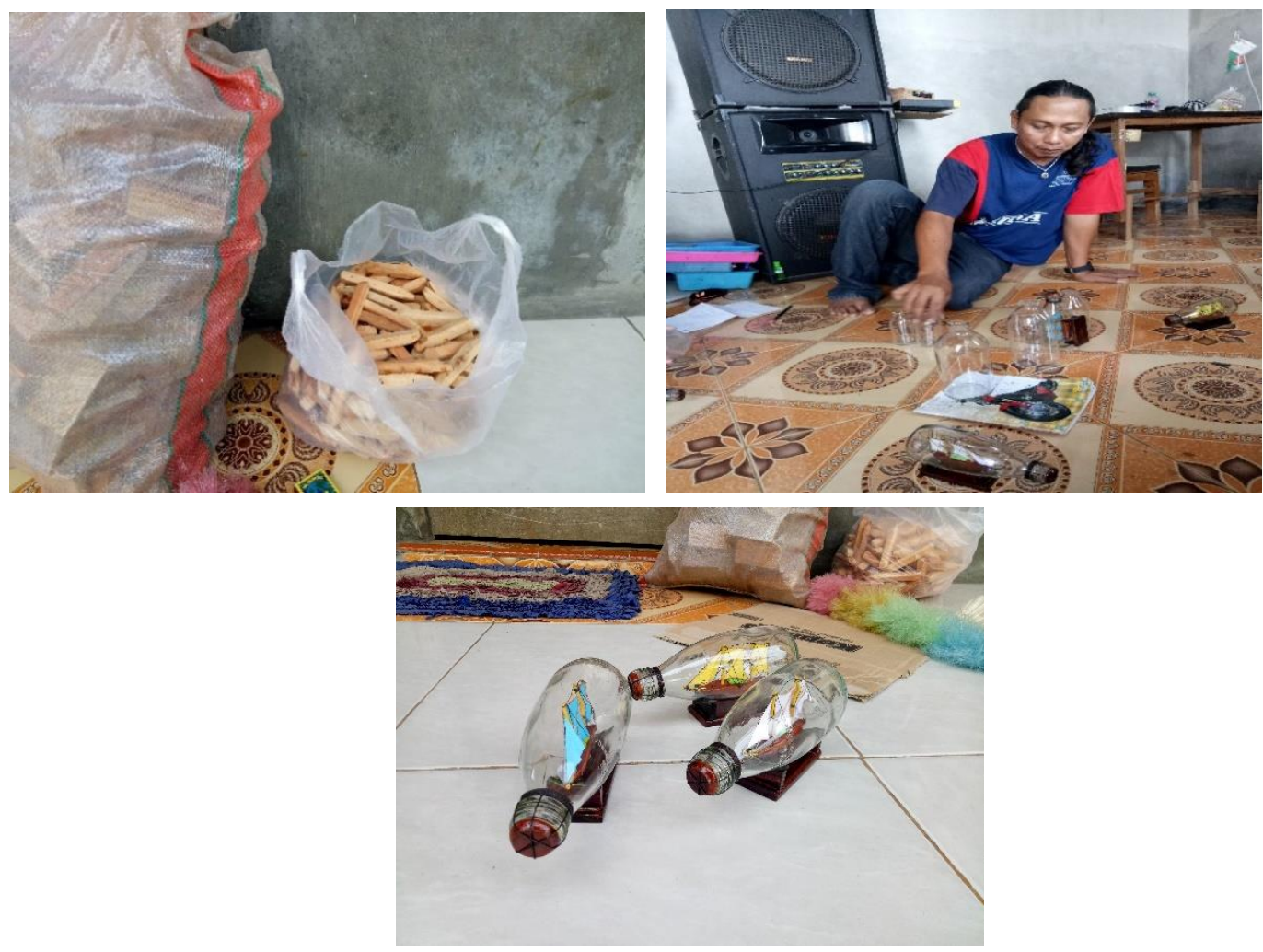

\section{Gambar 1. Bahan Baku dan Proses Pembuatan Handycraft}

Sebagai salah satu perguruan tinggi swasta di Surakarta, Sekolah tinggi Ilmu ekonomi Surakarta dalam menjalankan Tri dharma dan juga memiliki visi " Tahun 2030 menjadi perguruan tinggi yang unggul dalam pemanfaatan teknologi informasi bidang ekonomi dan ekonomi kreatif tingkat nasional serta berkarakter entrepreneur" sudah sewajarnya selalu memberikan pendampingan kepada pengrajin UMKM yang ada di sekitar Solo raya dalam meningkatkan ekonomi kreatif.

Dari fenomena yang ada perlu dukungan dan dilakukan pendampingan agar pengelolaan menjadi lebih baik dan memiliki manfaat untuk agung Handycraft sendiri dan masyarakat sekitar. Promosi tentu saja sangat diperlukan dan penjualan bisa ditingkatkan melalui e-marketing. Pemanfaatan e-marketing bukan tanpa kendala, ada beberapa hal yang harus diketahui dan dipelajari agar prosesnya berjalan dengan lancer dan konsumen merasa puas. Pengelolaan SDM juga dioptimalkan agar tidak menghambat produksi. Pengelolaan keuangan yang ternyata bisa dilakukan dengan bantuan program computer juga harus dimanfaatkan dan ditingkatkan. 


\section{METODE PELAKSANAAN}

Dalam pelaksanaan program pengabdian ini metode yang dilaksanakan adalah sebagai berikut :

\section{a. Pengenalan Kewirausahaan dan e-Marketing}

Pengenalan ini dilakukan dengan cara memberikan pelatihan materi kewirausahaan yang isinya memberikan review tentang dunia usaha dan tata cara berbisnis serta bagaimana menghadapi para kompetitor/pesaing di era digital sekaligus menyampaikan penyusunan pembuatan website dalam pembelajaran e-marketing membantu pemasaran yang disesuaikan dengan yang diinginkan UMKM namun bisa bermanfaat untuk semua anggotanya.

\section{b. Pengenalan Manajemen dan Keuangan}

Penyampaian materi Pengantar Manajemen dan Keuangan UMKM, materi yang diberikan merupakan keuangan dasar dari sebuah usaha yang bertujuan memberikkan ilmu dan petunjuk kepada UMKM agar nantinya manajemen keuangan UMKM dapat dipisahkan antara kepemilikan pribadi dan usaha seperti yang diinginkan organisasi selama ini bisa dikelola dengan baik dan profesional.

\section{HASIL DAN PEMBAHASAN}

Kegiatan pengabdian dilakukan dengan tema yang diberikan fokus pada bagaimana pemasaran bisa dilakukan dengan menggunakan e-marketing dan pengenalan website dan perencanaan keuangan pada agung Handycraft.

\section{Pengenalan Kewirausahaan dan -Marketing}

Dengan adanya motivasi ini para peserta kembali terdorong untuk berani memulai (atau melanjutkan) untuk berwirausaha. Rasa pesimis yang awalnya melanda para peserta dalam menghadapi situasi pandemi, telah hilang berkat adanya pemberian motivasi ini. Pada dasarnya para peserta sudah menyadari bahwa salah satu kesempatan untuk bekerja dalam masa saat ini adalah dengan bekerja sendiri, mandiri, yaitu berwirausaha. Kecil kemungkinan bagi mereka bila berharap hanya mendapatkan pekerjaan dari perusahaan yang diinginkan terlebih dengan banyaknya perusahaan yang menutup gerai, menyatakan pailit, maupun banyak melakukan PHK karyawan. 


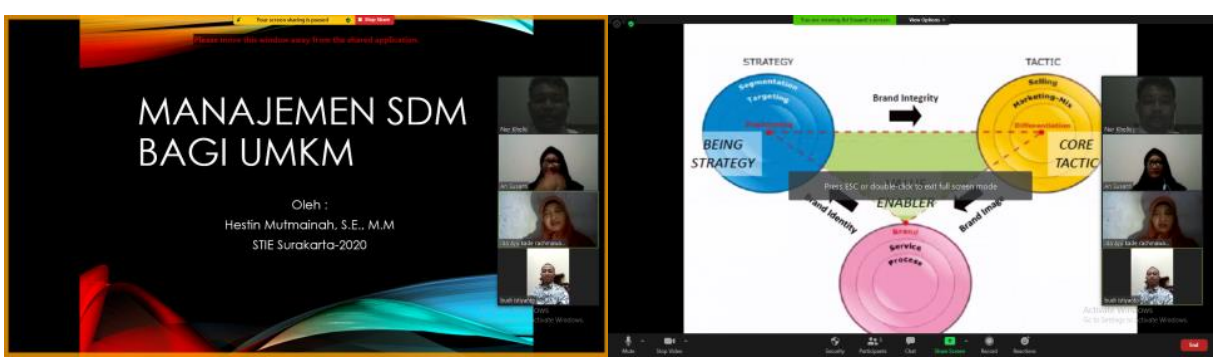

Gambar 2. Pemberian Materi Kewirausahaan

Di samping motivasi kewirausahaan pengenalan website dan pemasaran juga disampaikan. Strategi marketing yang banyak digunakan dalam kondisi seperti pandemi saat ini adalah e-marketing dengan menggunakan website. Ada banyak faktor yang perlu digali bilamana ingin menggunakan strategi ini, seperti persepsi masyarakat, tingkat kepercayaan masyarakat, keterjangkauan dari e-marketing akan mempengaruhi keberhasilannya. Literasi akan sisi positif sekaligus negatif dari e-marketing ini dapat membuka dan menambah wawasan bagi agung Handycraft agar lebih siap menggunakan strategi pemasaran ini. Adanya review materi e-marketing dapat menggunakannya sebagai salah satu alternatif strategi pemasaran yang cocok di masa pandemi. Sebenarnya agung Handycraft sudah menggunakannya dalam lingkup terbatas, ke depannya diharapkan dengan jangkauan yang lebih luas.

\section{Pengenalan Manajemen dan Keuangan UMKM}

Modal awal yang dimiliki ataupun digunakan dalam aktivitas usaha pada awalnya jumlahnya biasanya tidak terlalu besar. Bukan berarti pengelolaannya juga seadanya atau bahkan tanpa pengelolaan. Segala aktivitas terutama penggunaan keuangan tentu akan lebih baik bila direncanakan sebaik mungkin. Fungsi dari anggaran tersebut agar ada pedoman kerja di berbagai bidang termasuk penjualan, produksi, keuangan dan sebagainya. Dalam anggaran ini pun bisa diperkirakan berapa harga pokok produknya sehingga bisa menentukan berapa harga jual yang diinginkan agar tidak timbul kerugian. Di sini juga bisa terlihat berapa laba (atau bahkan rugi) yang akan dialami sebagai akibat dari berbagai aktivitas yang dilakukan baik pengeluaran maupun pemasukan kas, sehingga bisa dilakukan tindakan tertentu bilamana diperlukan. 

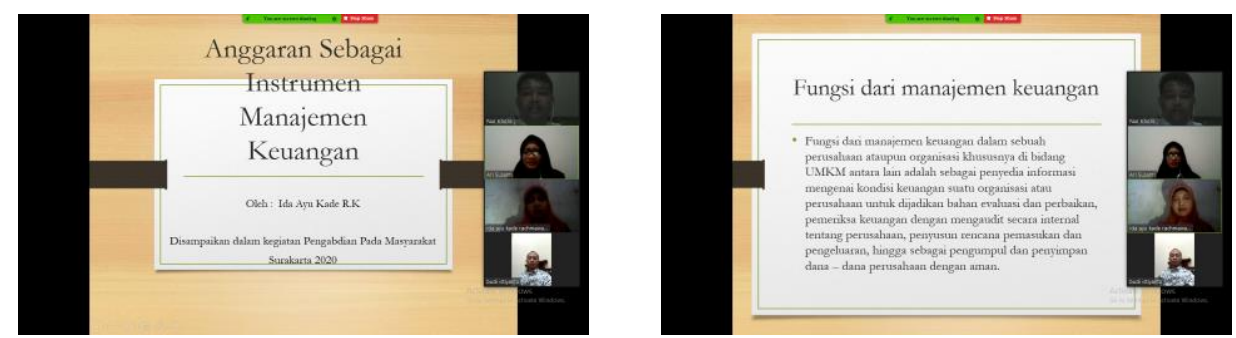

Gambar 3. Pemberiaan Materi Manajemen

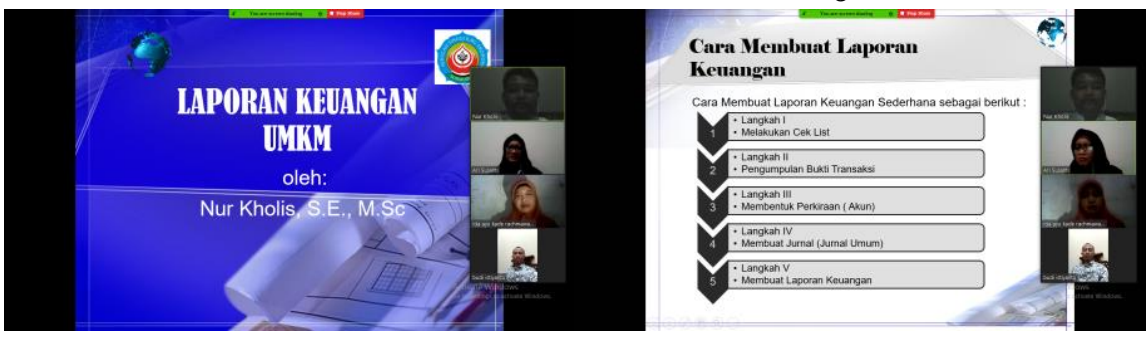

Gambar 4. Pemberian materi Keuangan dasar

Di samping materi tentang manajemen, juga diberikan materi tentang akuntansi Usaha Mikro Kecil Menengah. Para peserta diberikan pemahaman bahwa walaupun usaha kecil tetap memerlukan pencatatan pembukuan yang baik dan informatif sesuai dengan kaidah akuntansi yang berlaku. Ada beberapa pencatatan dasar yang harus dilakukan seperti arus kas masuk maupun keluar dengan jurnal umum, laporan posisi keuangan, serta laporan laba rugi. Saat ini ada beberapa program akuntansi sederhana yang bisa digunakan termasuk bila ingin menggunakan program Excel yang selama ini cukup familier. Sehingga pelaku Usaha mikro kecil menengah mengetahui seberapa laba dan tidak bisa memperkirakan biaya apa saja yang timbul dalam kegiatan usahanya dan mampu memisahkan keuangan usaha dan keuangan keluarga.

\section{SIMPULAN}

Program kegiatan pengabdian sudah dilakukan dengan baik dengan pelatihan softskill dan hardskill yaitu pemberian pengenalan kewirausahaan dan e-marketing serta pengenalan manajemen dan keuangan dengan harapan mampu membantu agung handycraft dalam membangun usaha dan mampu meningkatkan perekonomian keluarga dan lingkungan sekitarnya serta mampu meningkatkan ekonomi di daerah klaten pada umumnya. Kegiatan seperti ini semoga bisa dilaksanakan secara kontinu, melibatkan lebih banyak peserta, meliputi lebih banyak aktivitas dan tatap muka, termasuk pendampingan yang dalam program ini juga masih dilakukan. 
Nur Kholis, Hestin Mutmainah \& Ida Ayu Kade Rachmawati Kusasih | 62

\section{DAFTAR RUJUKAN}

Alma, Thomas. (2009). Kewirausahaan untuk Mahasiswa dan Umum. Bandung: Alfabeta.

Aditya, D. (Juli 2020). Terdampak Pandemi Virus Corona, sejumlah Perusahaan Besar di Dunia ini Bangkrut. Pikiran-Rakyat.com Diunduh dari laman https://galamedia.pikiran-rakyat.com/news/pr35596506/terdampakpandemi-virus-corona-sejumlah-perusahaan-besardi-dunia-ini-bangkrut

Bateman, Thomas S. (2014).Pengantar Manajemen. Jakarta: Salemba Empat.

Mukaromah, V. F. (2020). Airy Tutup, Ini Daftar 6 Perusahaan yang PHK Karyawan karena Corona,. Kompas.com. Diunduh dari laman https://www.kompas.com/tren/read/2020/05/08/152300365/airy-tutupinidaftar-6-perusahaan-yang-phk-karyawan-karena-corona?page=all.

Profil Agung Handycraft, Kabupaten Klaten

Rohmi, Nur. (2020). Refleksi Perekonomian Indonesia 2020 dan Harapan pada tahun 2021. Kompas.com Diunduh dari laman. https://www.kompas.com/tren/read/2020/12/19/180200765/refleksiperekonomian-indonesia-2020-dan-harapan-pada-2021-?page=all

Sumarsan, Thomas. (2011). Akuntansi Dasar \& Aplikasi Dalam Bisnis, Jakarta: PT Indeks. 